\title{
Neuroscience Application for the Analysis of Cultural Ecosystem Services Related to Stress Relief in Forest
}

\author{
Sandro Sacchelli ${ }^{1,2}$, Gianluca Grilli ${ }^{1,3,4, *}$, Irene Capecchi ${ }^{1}$, Lorenzo Bambi ${ }^{5}$, Elena Barbierato ${ }^{1}$ \\ and Tommaso Borghini ${ }^{5}$ \\ 1 Department of Agriculture, Food, Environment and Forestry, University of Florence, 50127 Florence, Italy; \\ sandro.sacchelli@unifi.it (S.S.); irene.capecchi@unifi.it (I.C.); elena.barbierato@unifi.it (E.B.) \\ 2 National Institute of Agribusiness and Sustainability (INAS), 50127 Florence, Italy \\ 3 Economic and Social Research Institute, Sir John Rogerson's Quay, D02 Dublin, Ireland \\ 4 Trinity College Dublin, D02 Dublin, Ireland \\ 5 Department of Architecture, University of Florence, 50127 Florence, Italy; lorenzo.bambi@unifi.it (L.B.); \\ tommaso.borghini@unifi.it (T.B.) \\ * Correspondence: gianluca.grilli@unifi.it
}

Received: 14 January 2020; Accepted: 3 February 2020; Published: 8 February 2020

\begin{abstract}
The paper presents an integrated methodology to assess psychological and physiological responses of people when exposed to forests, with the main objective of assessing the suitability of different stands for stress recovery on the basis of tree species and density. From the methodological viewpoint, the study applies both a Restoration Outcome Scale (ROS) questionnaire and a neuroscientific technique grounded on electro-encephalographic (EEG) measurement. Results show different outcomes for conifers and broadleaves as well as a statistical significance of density in the evaluation of an individual's emotional state. A forest with a high density of conifers and low density of broadleaves seems to be the proper combination for stress recovery. The differences among psychological stated preferences and EEG trends highlights potential conflict among "needs" and "wants" of people in the topic of stress relief. Potential applications of the research for health care and territorial marketing operations are suggested.
\end{abstract}

Keywords: sustainable forest management; stress recovery; emotional status; neuroscience

\section{Introduction}

The Millennium Ecosystem Assessment [1] highlights how the constituents of the well-being of individuals (safety, raw materials, health, good social relations, freedom of choice and action) are closely correlated with the ecosystem services provided by natural environments. Among these constituents, the analysis of the psycho-physical wellness component is becoming increasingly important for a sustainable and responsible management of natural and semi-natural ecosystems. The therapeutic effects of natural environments, including urban green spaces and gardens, is well-known and extensively reported in the literature. Several cities have been equipped with healing gardens for restoration from stress [2], because people tend to associate urban environment with stress and relaxation with natural environments [3]. Horticultural therapy is also gaining popularity to improve mental well-being [4].

As recently underlined in Marušáková and Sallmannshofer [5] the industrialized society in general and the European society in particular are influenced—especially in urbanized areas—by global trends and demographic changes, a cause of mental stress and associated physical diseases. The contribution of natural environments for stress relief is a topic of growing interest in the scientific literature, because of the increasing people's need to slow down from the frenetic and stressful city life [6]. As a result, the 
issue of providing an adequate supply of green spaces within cities and more natural areas for leisure close to cities has become an important topic in urban and regional planning [7,8]. Stress has both psychological and physiological effects on human body and therefore there are multiple indicators that can be used to study restoration effects of nature. Bowler et al. [9] carried out a systematic review to assess whether an association exists between health and exposure to natural environments, finding that almost all papers suggested a positive relationship although they concluded that more research is needed. The benefits of green spaces have been studied using a large set of indicators. One of the most common methods to test individual effects of exposure to nature is to use self-reported measures, for example Hazer et al. [10] used self-rates for stress in a study in Baltimore. Self-rates were also used to assess the effect of surrounding greenness on well-being and the connection with social relations [11].

Hansmann et al. [12] proposed a study on stress reduction caused by forests in Switzerland using self-assessed measures of well-being, headache and stress, suggesting that positive effects increase with the time spent in forest. Their study was based on three subjective measures of well-being that did not belong to any particular scale proposed in the literature. Among the set of scales for stress self-reporting the Psychological Stress Measure PSM-9 [13], composed of nine items, and PANAS, which uses ten descriptors [14], are often used in empirical studies. The Restoration Outcome Scale (ROS) is another popular choice for analysists [15], which is also the scale causing the least effort for respondents as it is composed by only six items; an empirical use of ROS for stress assessment in environmental settings is provided by Tsunetsugu et al. (2013). The analysis of individual self-reported measures is often accompanied by indicators to detected stress via physiological status. For example, the examination of cortisol levels in saliva samples [16,17], blood pressure, nervous activity and heart rate measurement $[18,19]$ are used. Data are collected through lab experiments in which the recruited sample is exposed to a particular type of environment during which psycho-physiological measurements occur. In addition to lab experiments, sample examination in real forests can be performed. This total immersion in woodland is often known as "forest bathing", "forest therapy" [20-22] or Shinrin-yoku, a Japanese term that indicates taking the atmosphere of the forest for restoration. Shinrin-yoku has been extensively studied by Park et al. [23-25] in different case studies involving comparison of salivary cortisol, cerebral activity and heart rate between urban and forest exposure. Results indicated lower cortisol levels, lower heart rate and increased cerebral activity in forests and a general positive effect of forest visit on relaxation. A literature review by Bratman et al. [26] shows how decreased exposure to nature causes changes in psychological functioning. Bratman et al. [27] investigated the role of nature experience on affect and cognition assessing changes in anxiety, rumination and negative affect.

More recently, tools of virtual reality (VR) are implemented in research and therapy. VR has the considerable advantage for analysts to reproduce natural environments and manipulate stimuli directly in the lab [28] allowing for a valuable trade-off between simplicity of stimuli presentation and effective immersion in forest. Bratman et al. [23] also review the latest advances in VR technology and its applications in neuroscience research for both natural and social analysis. Annerstedt et al. [29] proposed a stress assessment exposing respondents to VR. The indicators used to measure stress levels were saliva sample analysis and cardiovascular data. During the experiment, stress was first induced to participants using stress tests, then the sample was split into treatments in which recovery to stress was assigned using virtual built environments, natural environments and natural environments plus sounds of nature. Their main conclusion was that the most effective stress recovery potential was experienced when natural environments were accompanied by sounds of nature. The valuable influence of forest on physiological status of people, compared with urban area, is rarely not confirmed [30] (Yu et al. 2018); however, this fact seems to be related to the dose-response effect [31] or quality of virtual environment. De Kort et al. [32] conclude that immersion enhances the restorative potential of a mediated natural environment but an interaction between screen size and restorative phase exist. An interesting investigation based on VR is the effectiveness of virtual nature in respect to real visit [33]. The authors affirmed that indirect nature experience also provided positive psychological and physiological effects, except for parasympathetic nerve activity. 
Despite the growing scientific literature on this topic, a few studies focus on the correlation between forest characteristic (e.g., dendrometric parameters and silvicultural treatment) and the level of stress. Ulrich et al. [34]. undertook a pioneer study on the differences between urban and natural environments on stress recovery, using self-rated scales, measures of muscle tension and blood pressure. Chiang et al. [35] concentrated on forest density analysis stressing how forest interior condition induced significant stress recovery. Seasonal variation was evaluated in Bielinis et al. [36] through the effect analysis of spring and winter forest bathing on psychological relaxation. Tyrväinen et al. [16] compared the effectiveness of natural and built environment for stress recovery in Finland. Self-reported stress measures and saliva samples were collected in each environment. Self-reported stress was significantly lower in natural environments while saliva sample did not evidence differences in cortisol levels. A similar non-significance in cortisol was also experienced by Beil and Hanes [17] in the USA. Both authors suggested that failure in finding differences may have been caused by the short length of the trips (20 $\mathrm{min})$; in fact, it is demonstrated that health benefits from nature environments increase with dose [37].

Following the stream of literature on the association between stress recovery and natural environments, this paper describes a lab experiment that has been carried out to investigate the association between different forest types and stress levels. The study collected both physiological and self-rated measure of stress that were compared across different treatments, represented by exposure to a built environment and four different types of forest. A novel aspect of the proposed approach is the use of electro-encephalogram (EEG) data to test physiological effects of different environments, compared to most frequently used saliva samples, heart rate and blood pressure. The main objective of the study was to identify whether some forest stands are more effective than others for stress relief from both the physiological and perceived point of view. We concentrate on monospecific stands (high forest) of broadleaves (Turkey oak and European beech) and conifers (black pine and Douglas fir). Two levels of density are used in the study (low and high). The density level derives from the compartment classification of Forest Management Plan-FMP-of Rincine located in the study area (see Section 2.1). This parameter is qualitative (no specific level of number of trees per hectare is defined in the FMP). While most of the previous studies focused only on differences between natural and built environments, to the best of the authors' knowledge this is the first study that attempts to identify differences across forest stands, which might be useful for forest planning, marketing and management. As an additional objective of this study, we contribute to the stated preferences literature testing the convergence of EEG analysis with preferences of respondents for different forest types and their willingness to visit (WTV) forests for stress recovery. Results from this study are useful to tailor effective management and marketing strategies for tourists seeking restoration.

\section{Method}

\subsection{Stimuli Registration and Presentation}

Stimuli were recorded as videos-including audio-through a spherical video camera. Stimuli were presented to the individuals through a VR experience using the HTC VIVE headset.

The stress trend across different landscapes was evaluated comparing EEG in artificial vs. natural area. In total, one video was recorded in an urban area and served as artificial landscape (city) while eight videos showed natural environments (forests). The study area is located in the Metropolitan City of Florence, with the artificial video recorded in the centre of Florence city and forest samples placed in the territory of Municipality Union of Arno and Sieve Valleys. The videos were recorded in winter (at the end of February), during the vegetative rest condition (Figure 1). 


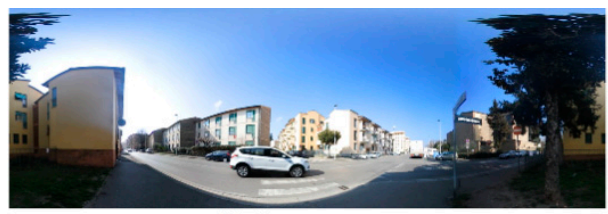

Urban area
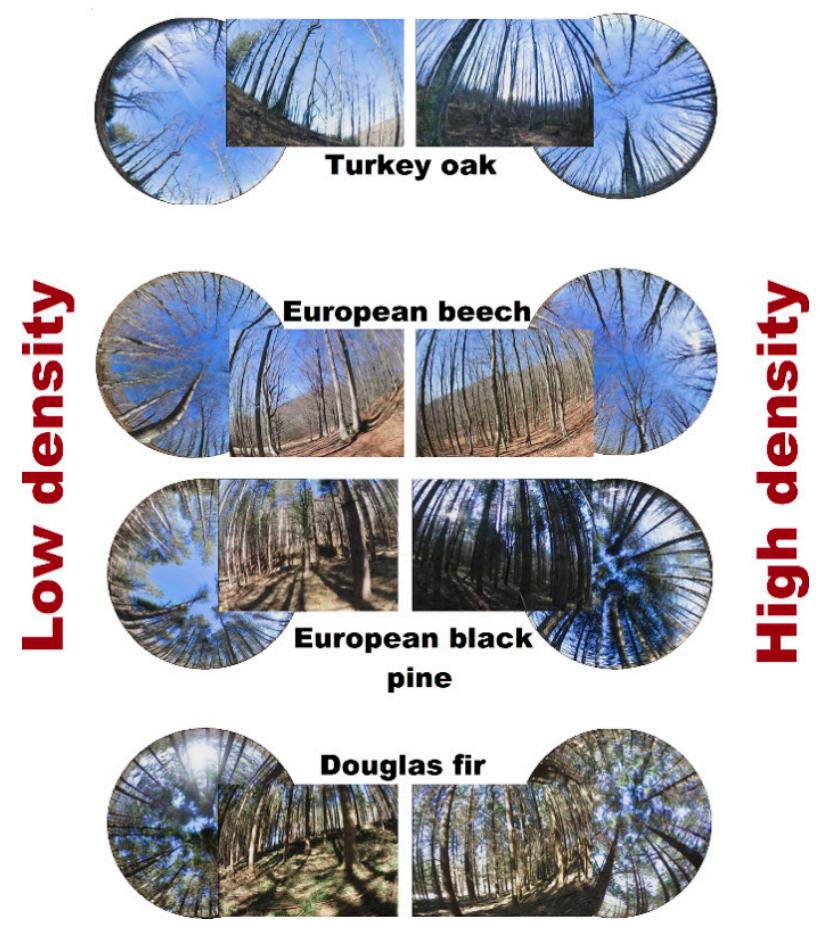

Figure 1. Screenshot from the applied VR video.

\subsection{Sample Recruitment and Interviews}

In order to facilitate recruitment and obtain a homogenous sample to calibrate the method, 20 subjects, $60 \%$ female and $40 \%$ male and between 21 and 28 years of age were interviewed. Studies have shown that students can represent the public on research involving visual stimuli [38]. The limited number of interviewed is in line with similar studies in the topic of VR application and EEG analysis $[39,40]$. The recruitment occurred within the Territorial, Urban and Environmental Planning course of the University of Florence and the sample included millennials that did not attend forestry science classes, in order not to affect preferences and perceptions of forests.

The sample was split into two gender-balanced sub-samples (T1 and T2) of equal size and each sub-samples received the following order of stimuli:

- T1: urban, Turkey oak (high density), Black pine (low density), European beech (high density), Douglas fir (low density);

- $\quad$ T2: European beech (low density), Douglas fir (high density), Turkey oak (low density), Black pine (high density), urban.

A questionnaire was used as a tool to collect the self-assessed stress levels with the ROS scale and the WTV data (Appendix A). The questionnaire included a first section that was administrated before showing the videos, with questions that captured socio-demographics such as age, gender, work situation and residence. Another section was administrated after the end of each video, where respondents had to answer to ROS scale, so that 5 different ROS scales were collected. This section was preceded by an introductory text that explained the questions and invited people to concentrate while filling in the scales. After the 4 videos showing forested area, respondents were also invited to express 
their WTV, thus giving 4 stated WTV for each respondent. A total of 5 treatments (or stimuli, 1 video of city and 4 videos of forests) were administered to each individual. The survey lasts approximately $15 \mathrm{~min}$. Every stimulus has a length of $30 \mathrm{~s}$. It was also included a target scene of $7 \mathrm{~s}$ after each treatment that was useful to reset the brain activity and bring the EEG levels back to normality (Figure 2). The questionnaire was administered in a neutral place (room) to guaranteed both full immersion and very low external interferences.

\section{First sample}

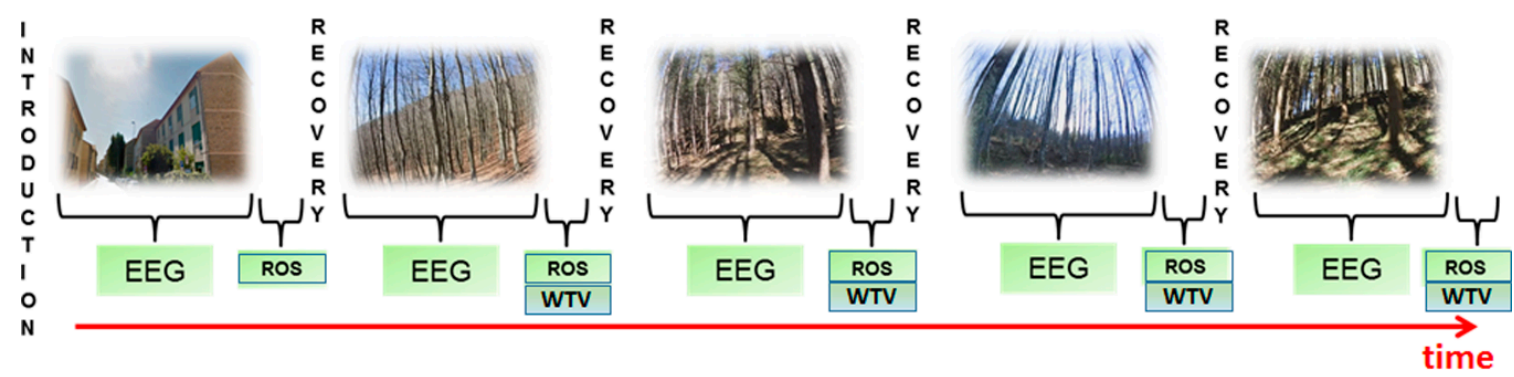

\section{Second sample}

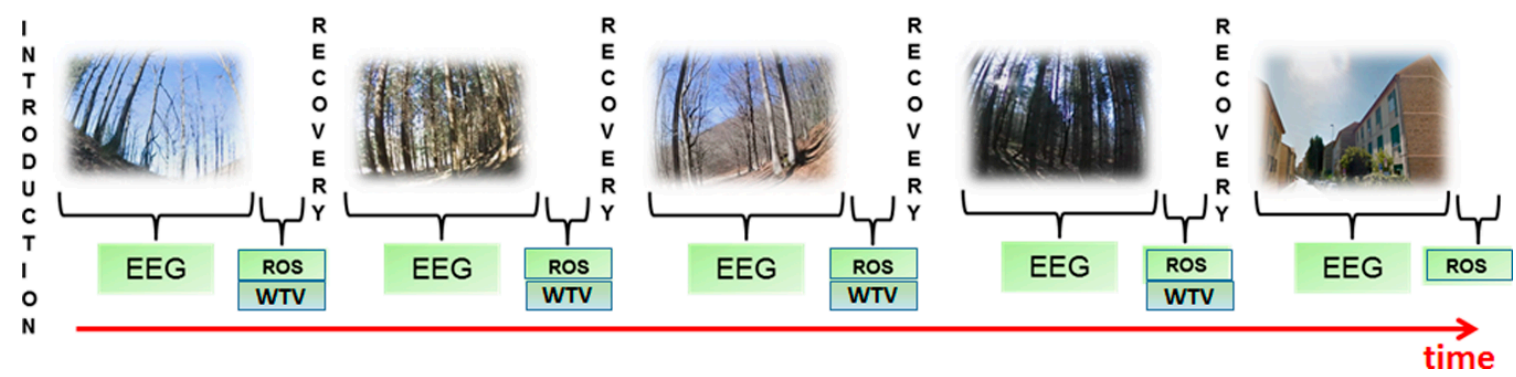

Figure 2. Sequence of stimuli presentation, EEG recording and interviews for first (T1) and second

(T2) samples.

\subsection{EEG Record}

The behavioural science has a long history of contributions to economics, for example with the identification of the heuristics used by respondents to simplify their decision making process [41,42] and with the study of context-dependence of the decisions [43-45]. However, inputs from neuroscience are still at their first stage and few papers analyse decisions with the aid of brain screening tools. For example, in two papers Sawe [46,47] applies functional magnetic resonance (fMRI) to assess cost-benefit to solve issues of interest in environmental valuation as well as the application in energy policy. Sawe and Knutson [48] proposed the use of neuroimages to evaluate respondents' willingness to donate money for natural parks' conservation.

The most applied technique is however EEG due to simpler and affirmed tools. EEG is the most common non-invasive brain sensing modality within Brain Computer Interface (BCI). EEG measures the electrical activity of brain around the scalp using electrodes [49]. With EEG, the user is able to read brainwaves oscillation in response to particular stimulus. The scientific literature classifies waves in five categories: alpha, beta, theta, gamma and delta. Each category is associated to a specific frequency (measured in hertz) and, indirectly, to a status of the individual. For the purpose of stress assessment, alpha and beta waves are the most suitable indicators [50]. We concentrated on beta waves because they are more reactive to short videos, while alpha need more exposure time to react to stress relief treatments [35]. The EEG stimuli were registered using the MuseBrain device, a wearable headband configured to analyse signals in TP9, AF7, AF8, TP10 scalp positions located in the frontal temporal lobe of the brain, according to 10-20 system EEG classifications [51]. 


\subsection{Statistical Analysis}

The impact of the five stimuli on brain activity is assessed with ANOVA techniques, which is carried out to test differences between groups with same sample sizes. Our data had some missing values generated by the EEG tool which makes the computation of ANOVA degrees of freedom problematic, so differences between the means were evaluated with the homologous OLS linear model, in which brain waves were regressed against dummy variables for each treatment. The two sub-samples T1 and T2 received videos with different tree densities, therefore we tested intra-specific differences on brain waves caused by density using $t$-tests. Stated answers for the ROS scale and WTV were analysed using ANOVA and Kruskal Wallis, as is common in the literature [16,17].

\section{Results}

\subsection{EEG Analysis}

Table 1 shows the means of brain absolute beta waves as well as the results of statistical tests for the five treatments. The tests highlighted that the four waves that we analysed (position AF7, AF8, TP9 and TP10 of MuseBrain electrodes) through the EEG screening were statistically different, with few exceptions. The urban environment treatment was found to give a non-statistically different activity of the wave AF7 compared to Turkey oak and a non-statistically different series of TP9 wave compared to pine and European beech. All other comparisons were significantly different and suggests that the urban environment is processed differently compared to other environments. With respect to forest treatments, Turkey oak showed an AF7 and AF8 activity non-statistically different to Black pine; the Black pine forest was also found to have a non-statistically different TP10 wave series compared to European beech.

Table 1. Mean values of beta waves and $p$-values of mean difference tests.

\begin{tabular}{|c|c|c|c|c|c|c|c|c|c|}
\hline \multicolumn{6}{|c|}{ Absolute Beta Waves } & \multicolumn{4}{|c|}{ Mean Difference Test } \\
\hline & af7 & af8 & tp9 & tp10 & & af7 & af8 & tp9 & tp10 \\
\hline \multirow[t]{2}{*}{ Urban } & 0.659 & 0.561 & 0.960 & 0.901 & $\begin{array}{l}\text { Urban vs. } \\
\text { Turkey oak }\end{array}$ & 0.530 & 0.000 & 0.000 & 0.000 \\
\hline & $(0.413)$ & $(0.348)$ & $(0.363)$ & $(0.441)$ & $\begin{array}{l}\text { Urban vs. } \\
\text { Black pine }\end{array}$ & 0.050 & 0.050 & 0.600 & 0.000 \\
\hline \multirow[t]{2}{*}{$\begin{array}{c}\text { Turkey } \\
\text { oak }\end{array}$} & 0.600 & 0.569 & 0.915 & 0.964 & $\begin{array}{l}\text { Urban vs. } \\
\text { European beech }\end{array}$ & 0.000 & 0.000 & 0.220 & 0.000 \\
\hline & $(0.454)$ & $(0.390)$ & $(0.316)$ & $(0.321)$ & $\begin{array}{l}\text { Urban vs. } \\
\text { Douglas fir }\end{array}$ & 0.000 & 0.000 & 0.000 & 0.000 \\
\hline \multirow[t]{2}{*}{$\begin{array}{l}\text { Black } \\
\text { pine }\end{array}$} & 0.636 & 0.545 & 0.974 & 0.866 & $\begin{array}{l}\text { Turkey oak vs. } \\
\text { Black pine }\end{array}$ & 0.190 & 0.120 & 0.000 & 0.000 \\
\hline & $(0.492)$ & $(0.409)$ & $(.473)$ & $(0.329)$ & $\begin{array}{l}\text { Turkey oak vs. } \\
\text { European beech }\end{array}$ & 0.000 & 0.000 & 0.000 & 0.000 \\
\hline \multirow[t]{2}{*}{$\begin{array}{l}\text { European } \\
\text { beech }\end{array}$} & 0.608 & 0.614 & 0.980 & 0.893 & $\begin{array}{l}\text { Turkey oak vs. } \\
\text { Douglas fir }\end{array}$ & 0.000 & 0.000 & 0.000 & 0.000 \\
\hline & $(0.419)$ & $(0.526)$ & $(0.324)$ & $(0.279)$ & $\begin{array}{l}\text { Black pine vs. } \\
\text { European Beech }\end{array}$ & 0.000 & 0.000 & 0.080 & 0.770 \\
\hline \multirow[t]{2}{*}{$\begin{array}{l}\text { Douglas } \\
\text { fir }\end{array}$} & 0.566 & 0.473 & 0.983 & 0.940 & $\begin{array}{l}\text { Pine vs. } \\
\text { Douglas fir }\end{array}$ & 0.000 & 0.000 & 0.000 & 0.000 \\
\hline & $(0.381)$ & $(0.419)$ & $(0.339)$ & $(0.371)$ & $\begin{array}{l}\text { European Beech } \\
\text { vs. Douglas fir }\end{array}$ & 0.000 & 0.000 & 0.000 & 0.000 \\
\hline
\end{tabular}

The $t$-tests that were used to test whether tree density had an effect on brain activity between the two subsamples returned a significant result for all the four waves ( $p$-value $=0.000$ ), suggesting that 
tree density is important for relaxation. Table 2 reports the means of absolute beta waves for species as well as density. Density has a strong correlation with EEG trend. Turkey oak and European beech show high value of absolute beta waves in case of high density, and vice versa for Black pine and Douglas fir.

Table 2. Mean of absolute beta waves for species and density.

\begin{tabular}{cccccc}
\hline & Turkey Oak & Black Pine & European Beech & Douglas Fir & Average \\
\hline High density & 0.8237 & 0.5892 & 0.8964 & 0.6527 & 0.7405 \\
Low density & 0.7167 & 0.9825 & 0.6865 & 0.8472 & 0.8082 \\
Average & 0.7702 & 0.7858 & 0.7914 & 0.7499 & \\
\hline
\end{tabular}

\subsection{ROS Scale Analysis}

Table 3 reports the means of the ROS items. The average values collected after the urban environment were lower than answers collected after forest environments, meaning that respondents indicated to feel more stressed after being exposed to videos showing urban areas compared to the stress levels after forests.

Table 3. Mean answers to Restoration Outcome (ROS) items after each EEG treatment.

\begin{tabular}{cccccc}
\hline & Urban & Turkey Oak & Black Pine & European Beech & Douglas Fir \\
\hline Item 1 & 2.5 & 3.2 & 3.45 & 3.4 & 3.55 \\
\hline Item 2 & 2.8 & 3.45 & 3.65 & 3.3 & 3.5 \\
\hline Item 3 & 3.1 & 3.45 & 3.6 & 3.2 & 3.3 \\
\hline Item 4 & 3.45 & 3.4 & 3.55 & 3.5 & 3.45 \\
\hline Item 5 & 2 & 3.15 & 3.15 & 2.75 & 3.15 \\
\hline Item 6 & 3.05 & 3.3 & 3.6 & 3.65 & 3.75 \\
\hline Total & 2.82 & 3.33 & 3.50 & 3.30 & 3.45 \\
\hline
\end{tabular}

Significance of differences is tested using ANOVA and the Tuckey test for binary comparisons as post hoc test. Results are reported in Table 4. Before the test, the Cronbach's $\alpha$ is calculated as a measure of internal consistency of the ROS questions. The ROS scale collected after the Turkey oak forest had a Cronbach $\alpha$ of 0.66 and a level of 0.71 after deleting question number 6 , all other values were above 0.70 and suggested adequate levels of internal consistency.

The ANOVA performed on the overall mean differences across treatments returned a $F$ statistic of 4.62 and a $p$-value of 0.0018 , therefore indicating that differences across the five ROS scales were greater than the interval variability of each scale. The Tuckey post hoc test for binary differences revealed that mean answers of ROS after the urban environment was statistically different from the ROS collected after all forest type. The mean values of ROS were instead not statistically different across forest stands. A test on whether the answers to ROS were statistically different across the two sub-samples (T1 and T2) and based on socio-demographics was also performed. While T1 and T2 were statistically different at $1 \%$ confidence level, no variation of ROS based on socio-demographics are detected. 
Table 4. ANOVA and Tuckey tests for differences in the ROS answers among the treatments.

\begin{tabular}{|c|c|c|c|c|c|c|c|}
\hline \multirow[t]{2}{*}{ Sample } & \multicolumn{2}{|c|}{ ANOVA } & \multicolumn{5}{|c|}{ Tuckey Test for Binary Comparisons } \\
\hline & F stat & $p$-value & Test & diff & lwr & upr & $\mathrm{p}$ adj \\
\hline \multirow[t]{10}{*}{ Full } & 4.62 & 0.0018 & Turkey oak-urban & 0.508 & 0.007 & 1.01 & 0.045 \\
\hline & & & Black pine-urban & 0.683 & 0.182 & 1.185 & 0.002 \\
\hline & & & European beech-urban & 0.483 & -0.018 & 0.985 & 0.064 \\
\hline & & & Douglas fir-urban & 0.633 & 0.132 & 1.135 & 0.006 \\
\hline & & & Black pine-Turkey oak & 0.175 & -0.326 & 0.676 & 0.868 \\
\hline & & & European beech -Turkey oak & -0.025 & -0.526 & 0.476 & 1 \\
\hline & & & Douglas fir-Turkey oak & 0.125 & -0.376 & 0.626 & 0.957 \\
\hline & & & European beech - Black pine & -0.2 & -0.701 & 0.301 & 0.801 \\
\hline & & & Douglas fir- Black pine & -0.05 & -0.551 & 0.451 & 0.999 \\
\hline & & & Douglas fir- European beech & 0.15 & -0.351 & 0.651 & 0.92 \\
\hline T1 vs. T2 & 6.89 & 0.01 & & & & & \\
\hline male vs. female & 2.1 & 0.15 & & & & & \\
\hline $\begin{array}{c}\text { workers vs. } \\
\text { non-workers }\end{array}$ & 1.46 & 0.23 & & & & & \\
\hline residence & 1.41 & 0.24 & & & & & \\
\hline $\begin{array}{l}\text { Childhood } \\
\text { residence }\end{array}$ & 0.37 & 0.82 & & & & & \\
\hline
\end{tabular}

\subsection{Willingness to Visit the Forests}

The last investigation regarded the stated probability of visiting the proposed forests to recover from stress and the maximum distance that respondents were willing to travel to reach a forest with the shown characteristics. The mean results obtained are reported in Table 5. Among the four forest types, the Douglas fir cover reported the largest probability of being visited and the longest distance that respondents were willing to travel, followed by Black pine, European beech and Turkey oak. We investigated whether these values were associated to EEG data but found no statistical evidence that beta waves are associated with stated WTV. The correlation coefficient between the mean wave values and the mean WTV data were very close to zero and non-significant, indicating statistical independence. The WTV was also not associated to socio-demographic variables, therefore we concluded that it is not possible to retrieve systematic patterns of WTV variation based on brain activity or individual characteristics.

Table 5. Probability to visit forests for stress recovery and willingness to visit (WTV) in $\mathrm{km}$.

\begin{tabular}{ccccc}
\hline & Turkey Oak & Black Pine & European Beech & Douglas Fir \\
\hline WTV & 2.65 & 3.25 & 2.75 & 3.35 \\
\hline (st. dev) & $(1.09)$ & $(0.91)$ & $(1.12)$ & $(0.99)$ \\
\hline WTV $(\mathrm{km})$ & 33 & 45 & 42.25 & 54.75 \\
\hline (st. dev) & $(20.42)$ & $(28.38)$ & $(33.50)$ & $(30.88)$ \\
\hline
\end{tabular}

\section{Discussions}

As a general comment, our results on EEG waves confirmed the available literature on the association between stress relief and exposure to natural environments $[17,19]$. We found that beta waves that were generated during the video on forests were significantly lower from the waves of the urban environment. At the same time, we found that the series of waves generated after each stimulus 
were also different within forest stands, therefore suggesting that different forest stands have different potential in stress relief, with Douglas fir stands to be the most effective. Conifers were found to be more appropriate for stress recovery compared to broadleaves. With respect to density, high density in conifers and low density in broadleaves resulted useful forest covers to improve the emotional status.

Interestingly, the output from ROS scales and WTV provided consistent results for what concerns differences between natural and built environments, suggesting that stated answers partially reflect the waves analysis. However, despite psychological responses were in line with the trend of EEG waves, differences across stands are not statistically significant for the self-rated stress items. This suggests that respondents understood that urban environments were more stressful than forest environments and-in winter conditions-conifers could be preferred in respect to broadleaves, but they were not fully able to provide self-assessments that reflect the underlying brain activity. This was even clearer for what concerns the stated WTV, which was proved to be totally uncorrelated to EEG results.

The study confirms the scientific literature on the topic showing the short-term restorative benefits of a visit to forests (also in VR environment). This effect is evident even in very short presentation time (thirty seconds per stimulus in our case study). Our results evidenced a good statistical significance of absolute beta waves. Other contributions found an association between relaxation treatments and alpha waves [35] and this may represent a topic of future investigation, provided that the treatment is long enough to allow alpha waves to react. An interesting further investigation could be related to the dose-response effect [17] between stimuli presentation and EEG value as suggested in Marušáková and Sallmannshofer [5]. Despite similar studies indicating that small samples are suitable for a reliable EEG analysis [50], it is difficult to generalize these findings and more research is required. Future improvements of the work can include a sample with larger age brackets and varying working conditions, which may be useful to detect correlation patterns among psycho-physiological trend and personal characteristics, as well as to focus on individual differences in nature exposure.

Spending time in nature is associated with good health outcomes, in particular when patients undertake activities such as gardening, which are useful for well-being and neuro-rehabilitation [52, 53]. Some hospital are now equipped with healing gardens to stimulate the contact of patients with nature [54] and horticultural therapy has been found to be a successful activity to alleviate dementia [55]. Within this context, forests may be important not only for prevention but also for rehabilitation and stress relief. Results from this study could be used and possibly deeper investigated to understand which parts of forested areas can be dedicated to healing, stress relief and prevention. Forest can be represented as a complex system [56], therefore there is not a unique approach to assure multi-objective management. Many quantitative and qualitative variables should be included to analyse stress relief effects. The present work introduces in a unique framework the evaluation of even-aged high forest characterised by different species and density but the registration of stimuli in winter season suggests repeating survey in vegetation condition. In fact, foliage can influence both psychological and physiological responses of respondents, giving a sense of more natural environment [57]. This assumption is confirmed by results related to density: in winter, higher density of conifers in respect to broadleaves seems to be better for stress recovery. In general, evidences about forest density perceptions are mixed. Jiang et al. [58] suggested that a medium vegetation level is associated with best performance in stress relief. On the other hand, Chiang et al. [35] demonstrated how forest interior induced best physiological outcomes in people although density seems not influence stress recovery. For this reason, future research on the effect of forest density on stress relief is important and, in particular, an improvement of our approach may consist in treating the density as a continuous variable instead of a simple binary. The colour of foliage in broadleaves forest should also has a weight on perception and physiological status suggesting an analysis in different vegetative seasons (e.g., spring/summer and fall). For example, our results suggest how EEG seem to improve in high-density conifer stands as well as low-density broadleaves. The evaluation of greenness indexes [59] in an intra-annual dynamic assessment could explain this finding. The presence of scrubs and other dominated vegetation plan should be also analysed. 


\section{Conclusions}

This paper proposed a method to evaluate the suitability of different forest stands for stress recovery and for the improvement of mood status. A combination of revealed preferences with EEG analysis has been proposed. The main innovation of our work is the simultaneous analysis of two variable (species and density) to evaluate forests in the perspective of complex systems, which were found to be important to model the stress recovery capacity from urban to forest visualisation.

Results confirmed that natural areas are important for stress relief. The winter survey denoted a preference for conifers, and in particular for Douglas fir, compared to broadleaves from both a psychological and physiological viewpoint. Forest density was strictly correlated with EEG data, which suggests that vegetation is relevant to alleviate stress levels and seasonality may impact the stress relief capacity of forests. The assertion of Norwood et al. [50] that affirms how "the positive effect of natural environments on mood is likely to occur via a brain-mediated process" is supported by our findings related to stated-preferences and EEG data. The statistically null correlation between EEG levels and willingness to visit indicates a difference between "wants" and "needs" of individuals. Despite being aware that our sample was too small to draw conclusions (in terms of number of interviewed categories), this findings was similar to previous research in the marketing field [60-62] and we believe that it is an interesting avenue for further research in environmental valuation.

The major implication of the work can be depicted in the assessment of forest variables important for stress recovery. Our preliminary results suggest how-for the winter season-high density conifers should be preferred for the promotion of the above ecosystem service. Future studies should investigate the amount of "greenness" during the different seasons to allow for dynamic forest management.

Future research may also focus on the analysis of uneven-aged forest, coppices, dendrometric variables (e.g., diameter of trees), presence/absence of renovation/scrubs to furnish useful information for forest managers aiming at adequate stands for forest therapy [63]. The integration of traditional (e.g., ROS questionnaire) and neuroscientific approach can be useful for the analysis of forests for people's well-being. In the framework of mix-method applications, future works could consider multi-criteria methods to investigate the association between forest stands and stress recovery. Combining these results with social, economic and logistic variables represents an innovative territorial marketing approach to promote close-to-city or inner-city areas. Based on the proposed method, a categorisation of forest for health promotion and disease prevention, mindfulness and forest bathing, outdoor and tourism as well as promotion of green jobs based on forest ecosystem services could be a future relevant issues to investigate.

Author Contributions: supervision, funding acquisition, field data acquisition, writing of Section 2.3 and writing of Section 5: S.S.; writing of Section 2.4, and writing of Section 3: G.G.; writing of Section 1: S.S. and G.G. in equal parts; sample recruitment and interviews, writing of Section 2.2: I.C. and E.B. in equal parts; laboratory tools management, writing of Section 2.1: I.C., E.B., L.B., and T.B. in equal parts; discussion and writing of Section 4: all authors in equal parts. All authors have read and agreed to the published version of the manuscript.

Funding: This study was conducted in the frame of the "Pianificazione strategica di impresa per la valorizzazione sostenibile delle filiere e dei servizi ecosistemici forestali" project, co-financed by Fondazione Cassa di Risparmio di Firenze. The APC was financed by UNICESV-Centro Universitario di ricerca per lo sviluppo competitivo del settore vitivinicolo of the University of Florence.

Acknowledgments: The authors would like to thank two anonymous reviewers for their helpful and stimulating comments and suggestions as well as A. Ventre and I. Battaglini for their valuable help in field investigations.

Conflicts of Interest: The authors declare no conflict of interest.

\section{Appendix A}

\section{QUESTIONNAIRE}

Section A - Socio-demographics (BEFORE the video)

$$
\text { - Male } \quad \square \quad \text { female }
$$


- Age

- Starting year of the Academic Career delayed graduation $\square$

- Are you a working student?

$\square$ Yes, I work on weekends

$\square$ Yes, part-time

$\square$ Yes, full-time

$\square$ No

- Do you regularly practice one of the following?

$\square$ Competitive sport

$\square$ Average-intensity physical activities

$\square$ sport activities on a regular basis (e.g.: dance classes)

- Do you own a personal mean of transport?

$\square$ I own a car

$\square$ I can use a car owned by one of my relatives any time I want to

$\square$ I can sometimes use a car owned by one of my relatives

$\square$ I own a motorbike/scooter that I exclusively use within the city

$\square$ I own a motorbike/scooter that I use for medium to long distances

$\square$ I do not have access to a private mean of betweennsport

$\square$ I do not have a driving licence

- Are you a member of an environmental association? Yes $\square \quad$ No

- Come descriverebbe il luogo dove risiede regolarmente?

$\square$ Big city (More than 100.000 inhabitants)

$\square$ Small City/town (between 25.000 and 100.000 inhabitants)

$\square$ Village (between 2.500 and 25.000 inhabitants)

$\square$ Small village (less than 2.500 inhabitants)

$\square$ Hamlet/ rural area

- How often do you go to natural areas such as forests and parks for recreational activities (e.g., hiking, walking, picnicking)?

$\square$ Almost Never (less than once per year)

$\square$ Rarely (1-2 per year)

$\square$ Sometimes (Once a month)

$\square$ Often (3-4 times per month)

$\square$ Very often (1-2 times per week)

\section{Introduction (To show BEFORE videos)}

It is well-known that natural areas have a relaxation and restorative function and some areas are better than others.

We will now show you some spherical videos that display different types of landscape. We ask you to carefully watch the videos and answer to six questions related to your psychological mind state. There are NOT right or wrong answers! We only ask you to answer naturally and as honestly as possible.

This is an example of question set: 


\begin{tabular}{|c|c|c|c|c|c|}
\hline $\begin{array}{l}\text { To what extend to you agree with the } \\
\text { following sentences? }\end{array}$ & $\begin{array}{l}\text { Strongly } \\
\text { disagree }\end{array}$ & Disagree & $\begin{array}{c}\text { Not agree } \\
\text { nor disagree }\end{array}$ & Agree & $\begin{array}{l}\text { Strongly } \\
\text { agree }\end{array}$ \\
\hline \multicolumn{6}{|l|}{ I feel healthy and relaxed } \\
\hline \multicolumn{6}{|l|}{ I feel calm } \\
\hline \multicolumn{6}{|l|}{$\begin{array}{l}\text { I feel powerful and ready for the } \\
\text { daily routine }\end{array}$} \\
\hline \multicolumn{6}{|l|}{ I feel attentive and careful } \\
\hline \multicolumn{6}{|l|}{ I can forget the daily problems } \\
\hline My thoughts are clear & & & & & \\
\hline
\end{tabular}

After each video we will ask you to consider visiting a similar forest to recover after a stressful period (e.g., after an examination or after a period full of commitments) and what is the probability that you choose it. The probability to choose the forest is also affected by its accessibility, with distant forests being less likely to be chosen because time and cost to reach it increase and vice versa. Assuming that the forest is close to your home enough to be visited with your own car (or public transport), we will also ask you the maximum distance that you are willing to travel to reach the forest for a daily excursion.

As before there are no right or wrong answers, we are only interested in understanding your preferences.

\section{SECTION B - To be presented after each VR video}

\section{Card with ROS questions}

\begin{tabular}{|c|c|c|c|c|c|}
\hline $\begin{array}{l}\text { To what extend to you agree with the } \\
\text { following sentences? }\end{array}$ & $\begin{array}{l}\text { Strongly } \\
\text { disagree }\end{array}$ & Disagree & $\begin{array}{c}\text { Not agree } \\
\text { nor disagree }\end{array}$ & Agree & $\begin{array}{l}\text { Strongly } \\
\text { agree }\end{array}$ \\
\hline \multicolumn{6}{|l|}{ I feel healthy and relaxed } \\
\hline \multicolumn{6}{|l|}{ I feel calm } \\
\hline \multicolumn{6}{|l|}{$\begin{array}{l}\text { I feel powerful and ready for the daily } \\
\text { routine }\end{array}$} \\
\hline \multicolumn{6}{|l|}{ I feel attentive and careful } \\
\hline \multicolumn{6}{|l|}{ I can forget the daily problems } \\
\hline My thoughts are clear & & & & & \\
\hline
\end{tabular}

Willingness to visit - To show after the video of forests (urban landscape excluded)

What is the probability that you choose this forest to recover after a stressful period?

\begin{tabular}{lllll}
\hline Very low & low & Not high nor low & High & Very high \\
\hline
\end{tabular}

- Assuming that you have easy access to this forest, what is the maximum distance (in $\mathrm{Km}$ ) that you are willing to travel for a day trip? 


\begin{tabular}{|c|c|c|c|c|}
\hline $\begin{array}{c}5 \\
(5-10 \mathrm{~min})\end{array}$ & $\begin{array}{c}10 \\
(10-15 \mathrm{~min})\end{array}$ & $\begin{array}{c}15 \\
(15-20 \mathrm{~min})\end{array}$ & $\begin{array}{c}20 \\
(20-25 \mathrm{~min})\end{array}$ & $\begin{array}{c}25 \\
(25-30 \mathrm{~min})\end{array}$ \\
\hline $\begin{array}{c}30 \\
(30-40 \mathrm{~min})\end{array}$ & $\begin{array}{c}35 \\
(35-45 \mathrm{~min})\end{array}$ & $\begin{array}{c}40 \\
(40-50 \mathrm{~min})\end{array}$ & $\begin{array}{c}45 \\
(45-55 \mathrm{~min})\end{array}$ & $\begin{array}{c}50 \\
(50-60 \mathrm{~min})\end{array}$ \\
\hline $\begin{array}{c}60 \\
(60-70 \mathrm{~min})\end{array}$ & $\begin{array}{c}70 \\
(70-80 \mathrm{~min})\end{array}$ & $\begin{array}{c}80 \\
(80-90 \mathrm{~min})\end{array}$ & $\begin{array}{c}90 \\
(90-100 \mathrm{~min})\end{array}$ & $\begin{array}{c}100 \\
(100-110 \mathrm{~min})\end{array}$ \\
\hline $\begin{array}{c}120 \\
(120-140 \mathrm{~min})\end{array}$ & $\begin{array}{c}140 \\
(140-160 \mathrm{~min})\end{array}$ & $\begin{array}{c}160 \\
(160-180 \mathrm{~min})\end{array}$ & $\begin{array}{c}180 \\
(180-200 \mathrm{~min})\end{array}$ & $\begin{array}{c}300 \\
(300+\min )\end{array}$ \\
\hline
\end{tabular}

\section{References}

1. Assessment-Mea, M.E. Ecosystem and Human Well-Being: Biodiversity Synthesis; Island Press: Washington, DC, USA, 2005.

2. Pouya, S.; Demİrel, Ö. What is a healing garden? Akdeniz Üniversitesi Ziraat Fakültesi Derg. 2015, 28, 5-10.

3. Marcus, C.C. Healing havens. Landsc. Archit. 2003, 93, 84-109.

4. Relf, P.D. The therapeutic values of plants. Pediatr. Rehabil. 2005, 8, 235-237. [CrossRef] [PubMed]

5. Marušáková, L.; Sallmannshofer, M.; Kašpar, J.; Schwarz, M.; Tyrväinen, L.; Bauer, N. Human Health and Sustainable Forest Management. FOREST, 2019.

6. Konu, H. Developing a forest-based wellbeing tourism product together with customers-An ethnographic approach. Tour. Manag. 2015, 49, 1-16. [CrossRef]

7. Moseley, D.; Connolly, T.; Sing, L.; Watts, K. Developing an indicator for the physical health benefits of recreation in woodlands. Ecosyst. Serv. 2018, 31, 420-432. [CrossRef]

8. Oosterbroek, B.; de Kraker, J.; Huynen, M.M.T.E.; Martens, P. Assessing ecosystem impacts on health: A tool review. Ecosyst. Serv. 2016, 17, 237-254. [CrossRef]

9. Bowler, D.E.; Buyung-ali, L.M.; Knight, T.M.; Pullin, A.S. A systematic review of evidence for the added benefits to health of exposure to natural environments. BMC Public Health 2010, 10, 456. [CrossRef]

10. Hazer, M.; Formica, M.K.; Dieterlen, S.; Morley, C.P. The relationship between self-reported exposure to greenspace and human stress in Baltimore, MD. Landsc. Urban Plan. 2018, 169, 47-56. [CrossRef]

11. Orban, E.; Sutcliffe, R.; Dragano, N.; Jöckel, K.-H.; Moebus, S. Residential surrounding greenness, self-rated health and interrelations with aspects of neighborhood environment and social relations. J. Urban Heal. 2017, 94, 158-169. [CrossRef]

12. Hansmann, R.; Hug, S.; Seeland, K. Restoration and stress relief through physical activities in forests and parks. Urban For. Urban Green. 2007, 6, 213-225. [CrossRef]

13. Lemyre, L.; Chair, M.R.; Lalande-Markon, M.-P. Psychological stress measure (PSM-9): Integration of an evidence-based approach to assessment, monitoring, and evaluation of stress in physical therapy practice. Physiother. Theory Pract. 2009, 25, 453-462. [CrossRef]

14. Watson, D.; Clark, L.A. Development and Validation of Brief Measures of Positive and Negative Affect: The PANAS Scales. J. Personal. Soc. Psychol. 1988, 54, 1063-1070. [CrossRef]

15. Hartig, T.; Lindblom, K.; Ovefelt, K. The home and near-home area offer restoration opportunities differentiated by gender. Scand. Hous. Plan. Res. 1998, 15, 283-296. [CrossRef]

16. Tyrväinen, L.; Ojala, A.; Korpela, K.; Lanki, T.; Tsunetsugu, Y. The in fluence of urban green environments on stress relief measures: A field experiment. J. Environ. Psychol. 2014, 38, 1-9. [CrossRef]

17. Beil, K.; Hanes, D. The Influence of Urban Natural and Built Environments on Physiological and Psychological Measures of Stress-A Pilot Study. Int. J. Environ. Res. Public Health 2013, 10, 1250-1267. [CrossRef]

18. Tsunetsugu, Y.; Lee, J.; Park, B.; Tyrväinen, L.; Kagawa, T.; Miyazaki, Y. Landscape and Urban Planning Physiological and psychological effects of viewing urban forest landscapes assessed by multiple measurements. Landsc. Urban Plan. 2013, 113, 90-93. [CrossRef]

19. Hartig, T.; Evans, G.W.; Jamner, L.D.; Davis, D.S.; Tommy, G. Tracking restoration in natural and urban field settings. J. Environ. Psychol. 2003, 23, 109-123. [CrossRef] 
20. Ochiai, H.; Ikei, H.; Song, C.; Kobayashi, M.; Miura, T.; Kagawa, T.; Li, Q.; Kumeda, S.; Imai, M.; Miyazaki, Y. Physiological and psychological effects of a forest therapy program on middle-aged females. Int. J. Environ. Res. Public Health 2015, 12, 15222-15232. [CrossRef]

21. Bielinis, E.; Takayama, N.; Boiko, S.; Omelan, A.; Bielinis, L. The effect of winter forest bathing on psychological relaxation of young Polish adults. Urban For. Urban Green. 2018, 29, 276-283. [CrossRef]

22. Ohe, Y.; Ikei, H.; Song, C.; Miyazaki, Y. Evaluating the relaxation effects of emerging forest-therapy tourism: A multidisciplinary approach. Tour. Manag. 2017, 62, 322-334. [CrossRef]

23. Park, B.; Tsunetsugu, Y.; Kasetani, T.; Hirano, H. Physiological Effects of Shinrin-yoku (Taking in the Atmosphere of the Forest)-Using Salivary Cortisol and Cerebral Activity as Indicators-. J. Physiol. Anthropol. 2007, 26, 123-128. [CrossRef] [PubMed]

24. Jin, B.; Yuko, P.Æ.; Tamami, T.Æ. The physiological effects of Shinrin-yoku (taking in the forest atmosphere or forest bathing): Evidence from field experiments in 24 forests across Japan. Environ. Health Prev. Med. 2010, 15, 18-26.

25. Park, B.; Tsunetsugu, Y.; Ishii, H.; Furuhashi, S.; Hirano, H.; Kagawa, T.; Miyazaki, Y. Physiological effects of Shinrin-yoku (taking in the atmosphere of the forest) in a mixed forest in Shinano Town, Japan. Scand. J. For. Res. 2008, 23, 278-283. [CrossRef]

26. Bratman, G.N.; Hamilton, J.P.; Daily, G.C. The impacts of nature experience on human cognitive function and mental health. Ann. N. Y. Acad. Sci. 2012, 1249, 118-136. [CrossRef] [PubMed]

27. Bratman, G.N.; Daily, G.C.; Levy, B.J.; Gross, J.J. The benefits of nature experience: Improved affect and cognition. Landsc. Urban Plan. 2015, 138, 41-50. [CrossRef]

28. Bohil, C.J.; Alicea, B.; Biocca, F.A. Virtual reality in neuroscience research and therapy. Nat. Rev. Neurosci. 2011, 12, 752-762. [CrossRef]

29. Annerstedt, M.; Jönsson, P.; Wallergård, M.; Johansson, G.; Karlson, B.; Grahn, P.; Marie, Å.; Währborg, P. Physiology \& Behavior Inducing physiological stress recovery with sounds of nature in a virtual reality forest-Results from a pilot study. Psychol. Behav. 2013, 118, 240-250.

30. Yu, C.-P.; Lee, H.-Y.; Luo, X.-Y. The effect of virtual reality forest and urban environments on physiological and psychological responses. Urban For. Urban Green. 2018, 35, 106-114. [CrossRef]

31. Powell, K.E.; Paluch, A.E.; Blair, S.N. Physical activity for health: What kind? How much? How intense? On top of what? Annu. Rev. Public Health 2011, 32, 349-365. [CrossRef]

32. de Kort, Y.A.W.; Meijnders, A.L.; Sponselee, A.A.G.; IJsselsteijn, W.A. What's wrong with virtual trees? Restoring from stress in a mediated environment. J. Environ. Psychol. 2006, 26, 309-320. [CrossRef]

33. Jeon, J.Y.; Yeon, P.S.; Shin, W.S. The influence of indirect nature experience on human system. For. Sci. Technol. 2018, 14, 29-32. [CrossRef]

34. Ulrich, R.; Simons, R.; Losito, B.; Fiorito, E.; Miles, M.A.; Zelson, M. Stress recovery During Expositure to Natural and Urban Environments. J. Environ. Psychol. 1991, 11, 201-230. [CrossRef]

35. Chiang, Y.-C.; Li, D.; Jane, H.-A. Wild or tended nature? The effects of landscape location and vegetation density on physiological and psychological responses. Landsc. Urban Plan. 2017, 167, 72-83. [CrossRef]

36. Bielinis, E.; Omelan, A.; Boiko, S.; Bielinis, L. The Restorative Effect of Staying in a Broad-Leaved Forest on Healthy Young Adults in Winter and Spring. Balt. For. 2018, 24, 218-227.

37. Shanahan, D.F.; Bush, R.; Gaston, K.J.; Lin, B.B.; Dean, J.; Barber, E.; Fuller, R.A. Health Benefits from Nature Experiences Depend on Dose. Sci. Rep. 2016, 6, 28551. [CrossRef]

38. Chang, C.-Y.; Chen, P.-K. Human response to window views and indoor plants in the workplace. HortScience 2005, 40, 1354-1359. [CrossRef]

39. Roe, J.J.; Aspinall, P.A.; Mavros, P.; Coyne, R. Engaging the brain: The impact of natural versus urban scenes using novel EEG methods in an experimental setting. Environ. Sci 2013, 1, 93-104. [CrossRef]

40. Yu, T.; Behm, H.; Bill, R.; Kang, J. Audio-visual perception of new wind parks. Landsc. Urban Plan. 2017, 165, 1-10. [CrossRef]

41. Kahneman, D.; Tversky, A. Prospect theory: An analysis of decision under risk. Econometrica 1979, 47, $263-291$. [CrossRef]

42. Tversky, A.; Kahneman, D. The framing of decisions and the psychology of choice. Science 1981, 211, 453-458. [CrossRef] 
43. Hanley, N.; Boyce, C.; Czajkowski, M.; Tucker, S.; Noussair, C.; Townsend, M. Sad or Happy? The Effects of Emotions on Stated Preferences for Environmental Goods. Environ. Resour. Econ. 2017, 68, 821-846. [CrossRef]

44. Notaro, S.; Grilli, G.; Paletto, A. The role of emotions on tourists' willingness to pay for the Alpine landscape: A latent class approach. Landsc. Res. 2018, 44, 743-756. [CrossRef]

45. Bassi, A.; Colacito, R.; Fulghieri, P. 'O Sole Mio: An Experimental Analysis of Weather and Risk Attitudes in Financial Decisions. Rev. Financ. Stud. 2013, 26, 1824-1852. [CrossRef]

46. Sawe, N. Using neuroeconomics to understand environmental valuation. Ecol. Econ. 2017, 135, 1-9. [CrossRef]

47. Sawe, N.I.K. Adapting neuroeconomics for environmental and energy policy. Behav. Public Policy 2018, 3, 17-36. [CrossRef]

48. Sawe, N.; Knutson, B. NeuroImage Neural valuation of environmental resources. Neuroimage 2015, 122, 87-95. [CrossRef]

49. Ruff, C.C.; Huettel, S.A. Experimental methods in cognitive neuroscience. In Neuroeconomics; Elsevier: Amsterdam, The Netherlands, 2014; pp. 77-108.

50. Norwood, M.F.; Lakhani, A.; Maujean, A.; Zeeman, H.; Creux, O.; Kendall, E. Brain activity, underlying mood and the environment: A systematic review. J. Environ. Psychol. 2019, 65, 101321. [CrossRef]

51. Klem, G.H.; Lüders, H.O.; Jasper, H.H.; Elger, C. The ten-twenty electrode system of the International Federation. Electroencephalogr. Clin. Neurophysiol. 1999, 52, 3-6.

52. Righetto, C.; Prosdocimi Gianquinto, G.; Orsini, F.; Meneghello, F.; Marcassa, G.; Koch, I.; Sgaravatti, P.; Piccolomini, B. Realization of a neuro-rehabilitation therapeutic garden: Design criteria and horticultural choices. Acta Hortic. 2016, 1121, 51-58. [CrossRef]

53. Wichrowski, M.; Whiteson, J.; Haas, F.; Mola, A.; Rey, M.J. Effects of horticultural therapy on mood and heart rate in patients participating in an inpatient cardiopulmonary rehabilitation program. J. Cardiopulm. Rehabil. 2005, 25, 270-274. [CrossRef]

54. Naderi, J.R.; Shin, W.-H. Humane design for hospital landscapes: A case study in landscape architecture of a healing garden for nurses. HERD Heal. Environ. Res. Des. J. 2008, 2, 82-119. [CrossRef]

55. Gigliotti, C.M.; Jarrott, S.E.; Yorgason, J. Harvesting Health: Effects of Three Types of Horticultural Therapy Activities for Persons with Dementia. Dementia 2004, 3, 161-180. [CrossRef]

56. Corona, P. Consolidating new paradigms in large-scale monitoring and assessment of forest ecosystems. Environ. Res. 2016, 144, 8-14. [CrossRef]

57. Kaplan, R.; Kaplan, S. The Experience of Nature: A Psychological Perspective; CUP Archive: Cambridge, UK, 1989; ISBN 0521341396.

58. Jiang, B.; Chang, C.-Y.; Sullivan, W.C. A dose of nature: Tree cover, stress reduction, and gender differences. Landsc. Urban Plan. 2014, 132, 26-36. [CrossRef]

59. Anderson, H.B.; Nilsen, L.; Tømmervik, H.; Karlsen, S.R.; Nagai, S.; Cooper, E.J. Using ordinary digital cameras in place of near-infrared sensors to derive vegetation indices for phenology studies of High Arctic vegetation. Remote Sens. 2016, 8, 847. [CrossRef]

60. Ariely, D.; Berns, G.S. Neuromarketing: The hope and hype of neuroimaging in business. Nat. Rev. Neurosci. 2010, 11, 284. [CrossRef]

61. Calvert, G.A.; Brammer, M.J. Predicting consumer behavior: Using novel mind-reading approaches. IEEE Pulse 2012, 3, 38-41. [CrossRef]

62. Khushaba, R.N.; Wise, C.; Kodagoda, S.; Louviere, J.; Kahn, B.E.; Townsend, C. Consumer neuroscience: Assessing the brain response to marketing stimuli using electroencephalogram (EEG) and eye tracking. Expert Syst. Appl. 2013, 40, 3803-3812. [CrossRef]

63. Chen, H.T.; Yu, C.P.; Lee, H.Y. The effects of forest bathing on stress recovery: Evidence from middle-aged females of Taiwan. Forests 2018, 9, 403. [CrossRef]

(C) 2020 by the authors. Licensee MDPI, Basel, Switzerland. This article is an open access article distributed under the terms and conditions of the Creative Commons Attribution (CC BY) license (http://creativecommons.org/licenses/by/4.0/). 